\title{
Propostes i criteris avaluadors per a la recerca a la $\cup A B$
}

\author{
Carme Picallo
}

V icerectora d'Investigació

A nivell informatiu, exposaré unes quantes xifres grosses sobre la recerca a l'Autònoma. Concretament, parlaré dels resultats que tenim fins ara dels projectes del Plan N acional, inclòs el darrer any, a tota l'Autònoma. D esprés, parlarem de les ciències, de les ciències socials en concret. Farem unes reflexions sobre això. Seguidament, donaré un informe a cada cap de departament amb dades sobre la recerca des de l'any 1995 fins al 1999. Faré uns comentaris sobre què ens diuen els números. A continuació us ensenyaré una gràfica. Recordeu que en el document d'avaluació de la recerca es va dir que es faria una simulació de quatre departaments de les quatre àrees de l'Autònoma, a veure quins resultats obteníem. Si us sembla, a continuació comentarem totes aquestes dades.

Començarem, per exemple, pels Planes $N$ acionales. Els números no són, per dir-ho així, gaire científics en aquest sentit, perquè estem parlant de grans xifres. Per tant, simplement n'he fet una mitjana, que varia segons els departaments, però és perquè se'n tingui una idea global.

Per exemple, de l'any 2000 els resultats que tenim dels projectes del Plan $\mathrm{N}$ acional ens diuen que en tota la UAB hi ha hagut un èxit del $60 \%$. És a dir, de tots els projectes que s'hi han sotmès, varien les àrees, però hi ha hagut un $60 \%$ d'èxit, és a dir, d'acceptats. Però, en canvi, dels projectes que s'han acceptat s'ha produït una forta retallada del que s'havia demanat. És il.lustratiu que, per exemple, la mitjana de l'Autònoma és del $30 \%$ concedit sobre el que s'ha demanat. Això té moltes interpretacions, però la primera és que hi ha hagut una forta retallada dels fons que generàvem.

Concretament, en ciències socials hi ha hagut un $48 \%$ d'èxit. $\mathrm{H}$ o he dividit en P1 i P2. Els P1 representen el $58 \%$ i els P2, el $28 \%$, i el concedit segueix la tònica general de l'Autònoma, ha estat d'un $30 \%$. No esmento els P3, perquè es van demanar dos projectes dels quals no se n'ha acceptat ni un. I no hi ha cap P4.

En aquest sentit, ciències socials no és l'àrea més castigada. L'àrea més castigada, i vull esmentar-ho, són les humanitats. És a dir, a humanitats hi ha hagut un $70 \%$ d'èxit de tots els projectes presentats, però, en canvi, no arriba al $26 \%$ de concedit. És a dir, dels projectes presentats, el $70 \%$ ha estat concedit, però, en canvi, de les quantitats demanades per a cada projecte, només se n'ha donat un $26 \%$. És a dir, una quarta part del que els projectes dema- 
naven. N o m'he mirat tots els projectes individualment, però per alguns la retallada és molt més punyent que per a altres, per dir-ho així. Fins al punt, que això ha provocat que en algun cas truquéssim a $M$ adrid per dir: «A veure, expliqueu-nos una mica...» perquè com a mínim, és sorprenent. Un dels casos concrets, recordo, no arribava al $12 \%$ del que s'havia demanat i era clarament deficient pel que es pretenia assolir. N o n'esmento ni l'àrea ni res, però era... sorprenent. H em fet trucades, hem demanat explicacions, llavors esperem que ens contestin.

Les dades que ara us comentaré, són les dades d'aquest departament, en concret des de l'any 1995 fins al 1999, on produeixen dos pics importants, quant a l'obtenció de recursos, que tenen lloc el 1996 i el 1998.

$\mathrm{H}$ i hauria molta cosa a dir, podríem discutir durant moltes hores, però permeteu-me que hi passi per sobre. Purament estem parlant de números molt grans. Els dos pics es produeixen sobretot gràcies a projectes europeus. Per exemple, l'any 1996, s'obté un xifra de 79 milions de pessetes en projectes europeus i el 98 , de 54 milions.

Llavors, un altre fet que crida l'atenció, també en línies molt generals, és, per exemple, que l'increment dels ingressos per convenis té un augment molt important des de l'any 1995. En canvi, els ingressos generals veiem que fan oscil-lacions, la qual cosa depèn dels projectes europeus. D e vegades hi ha una allau de sol-licituds, i això fa que les xifres vagin pujant i baixant. Però, en canvi, els convenis que no depenen de convocatories explícites en un moment donat, es veu que fan una pujada molt important des de l'any 1995.

Torno a repetir les xifres fins al 1999. No tinc les xifres del 2000.

Aquest és el segon comentari. Ja us dic, no m'hi estenc més... perquè ara es tractaria d'anar comentant ja número per número.

Respecte al tercer tipus de dades que us volia comentar, us ensenyaré el que se'n diu un blind test. Tractarem com a base el document d'avaluació de la recerca. Es va quedar d'acord amb la Junta de G overn, i amb la Comissió d'Investigació, que es faria una simulació agafant quatre departaments diferents de cada una de les àrees. Llavors això ens indicaria si hi ha hagut algun vici important, per dir-ho així, o algun esbiaixament important. Com ja sabeu, aquest document ha passat per catorze versions discutides durant dos anys per la Comissió d'Investigació. $H$ an tingut Iloc tot tipus de qüestions, s'hi han inclòs aspectes, àrees o activitats de recerca que no s'havien pensat en un principi, per exemple. Se n'ha modificat l'assignació de punts, tenint en compte tots i cada un dels suggeriments que ens anaven arribant..., que es podien argumentar bé. Llavors, sha arribat a un document que jo crec que és de consens, en certa manera, perquè no satisfà gaire els de ciències ni els de lletres. Per tant, potser estem en un terme mitjà.

Sabeu que a les gràfiques hi havia punts que s'assignaven als departaments per accions del tipus: organització de congressos, etc. Aquest tipus d'activitats que són pròpies de departament. I després punts que se sumaven a l'activitat del departament, però que els obtenien els investigadors individualment, que 
són els treballs que escriuen sobre les excavacions que fan, etc., els articles de revistes, llibres que s'escriuen..., en fi. Llavors, tot això està puntuat en relació amb el pes científic de les activitats.

Els PART T són els Punts d'Activitat de Receca i Transferència de Tecnologia i ens indiquen una xifra de 711 per al Departament d'H umanitats. Al D epartament de Ciències de la Salut és de 1.144. A Ciències Socials és de 853 i a Ciències Experimentals, 638. Aquests són els grans números. A ra, si dividim aquestes franges per punts aportats pels investigadors individuals o per punts aportats pels departaments, aleshores són els mateixos punts, però això correspon als dels departaments. És a dir, aquests són relatius a activitats departamentals i aquests són punts aportats per l'activitat individual de tots els investigadors.

Si només sumem les dades dels departaments, veurem que a Ciències Socials hi ha les activitats departamentals següents: organització de congressos, real ització de tesis doctorals, estades de recerca o docència de tercer cicle a la UAB, organització de fòrums de recerca i de transferència de tecnologia amb participació d'empreses $i$ altres institucions de la U AB col-lecció de documents de treball working papers o revistes de recerca.

Això indica que, en aquests ítems en concret, els departaments de Ciències Socials tenen una activitat molt més alta que la resta de departaments 0 de grups de departaments de la Universitat Autònoma.

En canvi, la xifra més el evada de punts obtinguts per investigadors és la de Ciències de la Salut, seguida immediatament pels departaments de C iències Socials.

Dins del departament, s'han fet divisions d'acord amb les activitats que hem explicat més amunt. Recordeu que el D epartament de Ciències Socials és el que té més activitat conjunta en aquest aspecte. És a dir, els departaments de Ciències Socials surten molt..., 0 accepten molta gent. Hi ha molta mobilitat, i a més activitat de lectura de tesi. M olta activitat acadèmica en aquest aspecte.

L'organització de congressos dels departaments de Ciències Socials dels quals estem parlant, és tan alta com la de Ciències Experimentals i molt per sobre de la resta és tan poc significativa que no apareix ni a Ciències $\mathrm{H}$ umanes, ni a Ciències de la Salut.

Pel que fa a les activitats dels investigadors, si en comparem les quatre àrees, veureu com varien. Per exemple, a Ciències de la Salut no s'escriuen Ilibres. La gent publica articles de revistes. És com la ciència avança en aquest aspecte. En canvi, a H umanitats, a l'altre extrem del campus, I'activitat per Ilibres de recerca és altíssima. Però clar, molta de l'activitat científica que té Iloc a H umanitats fa que s'hagin d'escriure llibres. Llibres de recerca.

Aquestes dades donarien per fer gairebé una sociologia, perdoneu l'expressió, de les diferents activitats. Fer un estudi de què vol dir això, i marca molt, a causa de l'especificitat purament de la investigació.

D e fet, però, si sumem totes les dades, veurem que les diferències no són significatives. Perquè els números són molt elevats. 
És molt curiós de veure la diferència entre els quatre gràfics. Q ue se'ns disparen els punts en alguns aspectes $i$ en els altres queden a zero, i tot això, quan ho sumes tot no és esbiaixat. Almenys és la impressió que en tenim nosaltres. La impressió i la reflexió de la Comissió d'Investigació. 